\title{
Graduate Student Literature Review: Current perspectives on whole-plant sorghum silage production and utilization by lactating dairy cows*
}

\author{
C. L. McCary, $† \odot$ D. Vyas, $\odot$ A. P. Faciola, $\odot$ and L. F. Ferraretto $₫ \odot$ \\ Department of Animal Science, University of Florida, Gainesville 32611
}

\begin{abstract}
The purpose of this literature review is to evaluate current research into and understanding of whole-plant sorghum silage production and the effect of feeding whole-plant sorghum silage on lactation performance of dairy cows. Sorghum's drought tolerance, water efficiency, and low cost of production make it an intriguing crop in areas where whole-plant corn silage production may be limited. Currently, urban land encroachment and reduced water availability have increased social and economic pressures on farms to improve crop production efficiency. As these challenges become more prevalent, greater reliance on sorghum can be expected because of its ability to produce high dry matter yields while maintaining nutritive value, even under less-than-ideal growing conditions. Moreover, whole-plant sorghum silage provides both physically effective fiber and energy through fiber and grain fractions. Advancements in sorghum genetics and mechanical processing have the potential to alleviate common challenges associated with whole-plant sorghum silage supplementation, such as increased neutral detergent fiber and decreased neutral detergent fiber digestibility, starch concentration, and starch digestibility. These nutritive challenges must be overcome for whole-plant sorghum silage to be a viable alternative to whole-plant corn silage.
\end{abstract}

Key words: berry processing score, brown midrib, ensiling, harvest maturity

\section{INTRODUCTION}

In 2018, approximately 2.5 million hectares of wholeplant corn silage (WPCS) was harvested in the United

Received December 24, 2019.

Accepted February 19, 2020.

*Submitted to the 2020 ADSA Foundation Graduate Student Literature Review Competition (Production Division, MS) on March 4, 2020.

†Corresponding author: cmccary@ufl.edu

‡Advisor (lferraretto@ufl.edu).
States (USDA-NASS, 2018). Despite the widespread use of WPCS, many regions are threatened with low water availability or conditions that may not be ideal for its growth. Negative consequences of these issues include loss of nutritive value and reduced whole-plant yields, which affect farm productivity and profitability. In this context, whole-plant sorghum silage (WPSS) has received interest because of its ability to be drought-tolerant and more water efficient than corn (Staggenborg et al., 2008). A 3-yr summary of sorghum production in the United States is shown in Table 1. In the 2018 growing season, over 100,000 ha of WPSS was harvested in the United States (USDA-NASS, 2018). Much of the harvested area of WPSS was in regions where WPCS growth may be limited. Generally, sorghum is adapted to dry climates such as that in the southwestern United States, but it has also been successfully grown in more moist and humid conditions such as the southeastern United States. The ability of sorghum to be grown across a wide variety of conditions may improve its potential use in the future. Several varieties of sorghum are available, including grain, forage, biomass, and sweet sorghum. Variation can be observed both physically and chemically between sorghum varieties and hybrids. Table 2 highlights some of the variation that can be observed in nutritive value depending upon the variety and hybrid selected. Careful variety and hybrid selection must occur to avoid selecting a variety or hybrid that may produce unexpected results at the time of harvest. Several challenges exist in supplementing WPSS to lactating dairy cows, including increased NDF and lignin concentrations and reduced starch concentration and starch digestibility. However, current research indicates that improvements through plant genetic advancement or mechanical processing may be able to alleviate some of these drawbacks. The purpose of this review is to provide current insights surrounding WPSS production and the effect of feeding WPSS on the lactation performance of dairy cows. As water availability issues continue and pressure is applied to the dairy industry to become more water efficient, sorghum could play an important role as a potential solution. 
Table 1. Summary of whole-plant sorghum silage production in the United States over a 3 -yr period ${ }^{1}$

\begin{tabular}{|c|c|c|c|}
\hline Item & 2016 & 2017 & 2018 \\
\hline Area harvested, ha & 120,596 & 114,121 & 106,837 \\
\hline Production, $\mathrm{Mg}$ as-fed & $3,783,872$ & $3,421,905$ & $2,957,426$ \\
\hline Yield, Mg/ha as-fed & 5.3 & 4.9 & 4.6 \\
\hline
\end{tabular}

${ }^{1}$ USDA-NASS (2018).

\section{WHOLE-PLANT SORGHUM SILAGE FRACTIONS}

Whole-plant sorghum silage is unique in that it contains a grain and a fiber fraction. We will discuss these fractions separately to evaluate the current knowledge related to improving each of their respective nutritive values.

\section{Grain Fraction}

Sorghum grain comprises 3 separate units - the pericarp, endosperm, and germ. The pericarp surrounds the outside of the seed and acts as a physical barrier to digestion of nutrients contained within the endosperm and germ layers.

The endosperm can be further divided into 2 sections: (1) floury, and (2) vitreous endosperm. Differences between the floury and vitreous endosperm are associated with protein concentration differences. In the vitreous endosperm, more storage proteins are intertwined with starch, which contrasts with the floury endosperm's lower concentrations of storage proteins (Shull et al., 1990). This gives the vitreous endosperm a glossy yellow appearance, whereas the floury endosperm is opaque.
These storage proteins, called kafirin proteins (Johns and Brewster, 1916), are defined as prolamin proteins. Kafirin proteins make up 60 to $70 \%$ of the total protein in sorghum grain and are the main storage protein, much like zein proteins in corn kernels (Duodu et al., 2003). However, kafirin proteins are more hydrophobic in nature and less digestible (Herrera-Saldana et al., 1990), and account for a greater percentage of the total protein of the grain than zein proteins in corn kernels (sorghum grain true protein contains $68.1-72.9 \%$ of true kafirin vs. corn grain true protein, which contains $50.4-56.2 \%$ of true prolamin, respectively; Hamaker et al., 1995). The binding and encapsulation ability of kafirin protein often acts as a physiochemical impediment to starch digestion in ruminants (Owens et al., 1986).

Overall, the majority of starch in sorghum grain resides in the endosperm. Starch concentrations are approximately $70 \%$ of DM of grain, with approximately $24 \%$ of starch being amylose (Sang et al., 2008). Amylose is characterized by a linear chain of D-glucose units linked by $\alpha(1-4)$ glycosidic bonds, and amylopectin consists of D-glucose units linked with $\alpha(1-4)$ glycosidic bonds and $\alpha(1-6)$ glycosidic bond branching points. Degradability of sorghum grain starch is generally accepted as being less than that of other grain sources, such as corn, barley, and wheat. Herrera-Saldana et al. (1990) quantified the in vitro starch degradation rates of corn, sorghum, wheat, barley, and oats and recorded rates of 6.4, 3.1, 23.5, 8.8, and $15.1 \% \mathrm{~h}^{-1}$, respectively. McAllister et al. (1990) quantified ruminal in situ DM degradability and fractions $\mathrm{A}, \mathrm{B}$, and $\mathrm{C}$ of $\mathrm{DM}$ after manually cut-

Table 2. Nutritive value of whole-plant sorghum silage samples submitted to a commercial laboratory ${ }^{1}$ in 2015

\begin{tabular}{lcccc}
\hline Item $^{2}$ & Average & Minimum & Maximum & No. of samples \\
\hline Moisture & 67.1 & 36.6 & 89.5 & 1,741 \\
CP, \% of DM & 10.5 & 3.88 & 17.1 & 1,677 \\
ADICP, \% of CP & 1.08 & 0.52 & 1.64 & 1,650 \\
Soluble CP, \% of CP & 42.7 & 17.9 & 67.4 & 1,208 \\
ADF, \% of DM & 38.9 & 28.7 & 49.3 & 1,672 \\
aNDF, \% of DM & 57.7 & 43.7 & 71.7 & 1,680 \\
Lignin, \% of DM & 5.72 & 3.28 & 8.17 & 879 \\
NDFD30, \% of NDF & 51.6 & 30.9 & 72.3 & 967 \\
NDFD240, \% of NDF & 72.6 & 55.5 & 89.7 & 1,273 \\
uNDFom240, \% of DM & 16.8 & 3.87 & 29.7 & 1,288 \\
WSC, \% of DM & 7.23 & 0.09 & 25.1 & 1,636 \\
Starch, \% of DM & 5.97 & $\mathrm{NR}^{3}$ & 21.7 & 1,300 \\
Ether extract, \% of DM & 2.85 & 1.45 & 4.25 & 1,303 \\
Ash, \% of DM & 10.8 & 2.20 & 19.5 & \\
\hline
\end{tabular}

${ }^{1}$ Dairyland Laboratories Inc. (Arcadia, WI).

${ }^{2} \mathrm{ADICP}=$ acid detergent insoluble $\mathrm{CP}$; aNDF $=$ concentration of NDF determined in the presence of heatstable $\alpha$-amylase, sodium sulfite, and inclusive of residual ash; NDFD30 = digestible NDF determined after $30 \mathrm{~h}$ of incubation in rumen fluid; NDFD240 = digestible NDF determined after $240 \mathrm{~h}$ of incubation in rumen fluid; uNDFom240 = undigestible NDF corrected for OM determined after $240 \mathrm{~h}$ of incubation in rumen fluid; WSC $=$ water-soluble carbohydrates.

${ }^{3}$ Not reported. 
ting barley, corn, wheat, and sorghum grains in half or leaving grains whole. The authors observed that when barley, corn, sorghum, and wheat grain were left whole and incubated in the rumen for $48 \mathrm{~h}$, whole grains were nearly indigestible $(11,14,19$, and $23 \%$ ruminal in situ DM degradability, respectively, after $48 \mathrm{~h}$ of incubation in the rumen). These results can be explained by the inability of rumen microbial populations to efficiently penetrate the pericarp. When McAllister et al. (1990) cut wheat, barley, sorghum, and corn in half, greater ruminal in situ DM degradability was observed $(P<0.01$; $50,31,25$, and $13 \%$ ruminal in situ DM degradability after $12 \mathrm{~h}$ of incubation in the rumen, respectively). These results underscore that sorghum grain must be broken to disrupt barriers, such as the pericarp and the starch-protein matrix, which inhibit DM degradation. Aggressive processing of sorghum grain increases the surface area available to digestive processes (McAllister et al., 1990; Johnson, 2017). However, mechanical processing of sorghum grain contained within WPSS is often difficult under field conditions. Therefore, further research is needed to quantify the relationship between grain processing, starch digestibility, and lactation performance. Finally, the germ is of lesser importance in terms of grain protection; however, it contains fatty acids and minerals important for dairy cattle.

Sorghum grain also contains polyphenols, specifically phenolic acids, flavonoids, and tannins (Duodu et al., 2003), which can have negative effects on animal intake and performance. Dykes et al. (2005) analyzed 13 sorghum varieties and observed that physical traits such as plant color, pericarp thickness, and the presence or absence of a pigmented testa were related to phenol concentrations. Among polyphenolic compounds, tannins have been shown to bind protein and starch and can lower starch digestibility (Barros et al., 2012). Hence, hybrids containing tannin must be managed to mitigate reductions of starch digestibility and subsequently negative effects on lactation performance.

\section{Fiber Fraction}

A widespread critique of WPSS is that it contains greater NDF, ADF, and lignin concentrations compared with WPCS (Aydin et al., 1999; Bernard and Tao, 2015). Subsequently, reduced digestibility of NDF (NDFD) has been observed when comparing conventional WPSS with WPCS (56.4 vs. $59.1 \%$ of NDF for conventional WPSS vs. conventional WPCS, respectively; Oliver et al., 2004). However, improvements of NDFD in WPSS have been made through genetic selection for the brown midrib (BMR) trait (Porter et al., 1978). Sorghum can exhibit the bmr gene at locus number 6,12 , or 18, commonly referred to in the literature as BMR-6,
BMR-12, or BMR-18, respectively (McCollum et al., 2005). Although BMR types reduce lignin concentrations, different mechanisms have been postulated. Sattler et al. (2010) explained that BMR-12 lowers caffeic $o$-methyltransferases activity, which is needed in the final step of the production of syringyl lignin, whereas BMR-6 reduces cinnamyl alcohol dehydrogenase, which produces coniferyl, coumaryl, and sinapyl alcohols, later used to produce $p$-hydroxyl lignin, guaiacyl lignin, and syringyl lignin. The mechanism of BMR-18 may be similar to that of BMR-12 because loci 12 and 18 are thought to be allelic (Oliver et al., 2004). Overall, BMR varieties are possibly the best example of how nutritive value can be improved through genetic advancement.

Aydin et al. (1999) compared BMR-6 WPSS with conventional WPSS, alfalfa silage, and conventional WPCS. The authors observed a $10.3 \%$ increase in NDFD with BMR-6 compared with conventional WPSS after $30 \mathrm{~h}$ of in situ incubation. Furthermore, ruminal NDF digestion kinetics were estimated. The fractional rates of NDF digestion were $3.3,4.9,10.3$, and $3.1 \% \mathrm{~h}^{-1}$ for conventional WPSS, BMR-6 WPSS, alfalfa silage, and conventional WPCS, respectively. The potential extent of NDF digestion at $96 \mathrm{~h}$ was 56.5, 64.6, 48, and $68.6 \%$ for conventional WPSS, BMR-6 WPSS, alfalfa silage, and conventional WPCS. Similarly, Oliver et al. (2004) observed that in situ NDFD was increased by $13.6 \%$ with BMR- 6 and by $7.1 \%$ with BMR-18 compared with conventional WPSS after ruminal incubation for $48 \mathrm{~h}$, when comparing a conventional WPSS, BMR-6 WPSS, BMR-18 WPSS, and a conventional WPCS. Rates of NDF digestion were $2.3,3.7,3.4$, and $3.6 \% \mathrm{~h}^{-1}$ for conventional WPSS, BMR-6 WPSS, BMR-18 WPSS, and a conventional WPCS, respectively. The potential extent of NDF digestion at $96 \mathrm{~h}$ was 70.4, 76.4, 73.1, and $79.0 \%$ for the same lines, respectively. The improvements in NDFD and NDF digestion kinetics presented by Aydin et al. (1990) and Oliver et al. (2004), imply that nutritive value and digestibility of whole-plant sorghum silage fiber are improved by the BMR trait compared with that of conventional WPSS, and that fiber nutritive value and digestibility may be equal to that of conventional WPCS. Recently, Sánchez-Duarte et al. (2019) used a meta-analytical approach and suggested that BMR WPSS hybrids have the potential to reach NDFD values similar to those of conventional WPCS hybrids.

\section{PREHARVEST FACTORS AFFECTING NUTRITIVE VALUE AND YIELD}

Many important decisions affecting the nutritive value and yield of a crop are made before harvest season begins. The following discussion aims to provide cur- 
rent knowledge of considerations that should be made before harvest.

\section{Planting Density and Plant Population}

Sorghum can tolerate wide varieties of planting populations. M'Khaitir and Vanderlip (1992) observed that planting densities of 15,000, 45,000, and 135,000 plants $\mathrm{ha}^{-1}$ had no effect on plant yield $(\mathrm{kg} / \mathrm{ha})$, although sorghum plants increased the number of seed heads per plant, compensating for any possible losses at lower planting densities. Conley et al. (2005) observed the ability of sorghum to adapt physiologically with plant populations of $74,131,148,263,222,394,296,526$, and 370,657 plants ha ${ }^{-1}$ over 2 yr. The authors observed differences in grain yield (bu/ha) between 74,131 and 148,263 plants $\mathrm{ha}^{-1}$ in both years $(P \leq 0.05 ; 278.9$ vs. $319.9 \mathrm{bu} / \mathrm{ha}$ for year 1 , and 259.4 vs. $284.9 \mathrm{bu} / \mathrm{ha}$ for year 2 , respectively). No differences were observed between any other plant populations. Similar to the study of M'Khaitir and Vanderlip (1992), Conley et al. (2005) concluded that the ability of sorghum to adjust the number of seed heads per plant influenced the lack of significant difference between grain yields of different plant populations.

Limited published research is available elucidating the effects of plant population on WPSS nutritive value and yield. Marsalis et al. (2010) quantified the effect of planting population and $\mathrm{N}$ application rate on $\mathrm{DM}$ yield and nutritive value of a conventional corn, conventional forage sorghum, and BMR forage sorghum hybrids over 2 yr in New Mexico. Sorghum was planted at rates of $185,185,214,815$, and 249,383 plants ha ${ }^{-1}$. The authors concluded that planting density and nitrogen application can be reduced without detrimental effects on DM yield. However, a combination of high planting rate and reduced $\mathrm{N}$ application could lead to lower CP concentrations.

Sorghum genetics are continually improving and, therefore, consistent reassessment of optimal planting rates to maximize yield and nutrient value is justified. Previously recommended planting density and plant population may be rendered obsolete as hybrid characteristics and tolerances adapt due to plant genetic advancement.

\section{Plant Maturity}

Sorghum grains can proceed from milk stage to soft dough to hard dough to physiological maturity over a 25- to 45-d period after flowering, depending upon the hybrid and climate (Gerik et al., 2003). The timing of harvest within this window is critical to capturing the desired nutrient value. Sonon and Bolsen (1996) observed that as sorghum plants matured from latemilk to late-dough to hard-grain $(25.4,30.0$, and $38.0 \%$ of DM, respectively), DM yield increased (11.2, 12.3, and $13.5 \mathrm{Mg}$ of DM ha ${ }^{-1}$, respectively) and the proportion of the silage that was grain increased as well (1.3, 3.5 , and $4.1 \mathrm{Mg}$ of $\mathrm{DM} \mathrm{ha}{ }^{-1}$, respectively). Because sorghum grain comprises primarily starch, the concentration of NDF in WPSS decreased from late-milk to late-dough to hard-grain $(60.2,54.1$, and $53.9 \%$ of DM, respectively). Lower NDF concentration is attributed to a dilution of NDF by increasing concentrations of starch with advancing plant maturity.

Recently, Lyons et al. (2019) evaluated the timing of harvest of BMR WPSS to maximize yield and nutritive value. Seven field trials across 2 locations in the northeastern United States were used. Harvests at each location were targeted at the boot, flower, milk, and soft dough stages. The authors concluded that harvest could take place at any of the tested harvest stages, depending upon the forage quality parameter desired. Early growth stages produced a crop with greater NDFD at $30 \mathrm{~h}(70,68.1,63$, and $60.7 \%$ of NDF for boot, flower, milk, and soft dough, respectively) and CP concentration (104, 94, 82 , and $80 \mathrm{~kg} / \mathrm{g}$, respectively), whereas later stages maximized DM yield $(10.7,13.4$, 15.2 , and $15.8 \mathrm{Mg}$ of $\mathrm{DM} /$ ha for boot, flower, milk, and soft dough, respectively) and starch concentration (66.3 82.7, 130.0, and $172.5 \mathrm{~g} / \mathrm{kg}$ of DM, respectively). Last, the effect of substituting BMR WPSS for conventional WPCS was evaluated. The authors predicted ME-allowable milk and MP-allowable milk of the diet with the Cornell Net Carbohydrate and Protein System (v. 6.55; Van Amburgh et al., 2015) while replacing conventional WPCS with BMR WPSS. Inclusion amounts of BMR WPSS were $0,25,50,75$, and $100 \%$ of the conventional WPCS in the diet. Overall, substitution of BMR WPSS for conventional WPCS varied by the growth stage harvested and, on average, the predicted ME-allowable milk decreased from $41.9 \mathrm{~kg} / \mathrm{d}(100 \%$ conventional WPCS) to $39.5,40.1,40.3$, and $41.1 \mathrm{~kg} / \mathrm{d}$ (100\% BMR WPSS) for the boot, flower, milk, and soft dough stages, respectively. The authors suggested that the similar values for ME-allowable milk could be due to the greater NDFD when comparing the conventional WPCS used in the study with BMR WPSS. Results for MP-allowable milk were more variable among the 7 trials performed. However, on average across all trials, MP-allowable milk was $43 \mathrm{~kg} / \mathrm{d}$ when only conventional WPCS was included in the diet, and as conventional WPCS was replaced with BMR WPSS, MP-allowable milk values of $42,43,42$, and $43 \mathrm{~kg} / \mathrm{d}$ for boot, flower, milk, and soft dough stages were observed, respectively. Based on these results, the authors concluded that replacement of conventional WPCS with BMR WPSS 
protein may be sufficient, but additional energy supplementation may be necessary.

\section{THE SILAGE-MAKING PROCESS}

Forage quality can have a significant effect on potential of milk yield from dairy cows and it is paramount to preserve the quality of forages throughout the harvest season. Waldo (1977) observed that the total efficiency of any preservation method is a function of several major factors, including recovery from the field, recovery from storage, intake, digestibility, efficiency of utilization, daily production, and production per hectare. Rotz et al. (2003) reviewed the use of silages in farming and observed that silage production and preservation methods can reduce harvest losses by reducing drying time in the field, providing more consistency in nutrient composition and increasing the ease of handling at mixing and feeding of total mixed rations. As average farm size increases, further emphasis will be put on efficient harvesting practices, storage of large amounts of feed, and consistency of nutrient content which can all be provided through the silage making process.

\section{Roll Gap and Theoretical Length of Cut Settings}

Historically, reduced theoretical lengths of cut were used to break the grain fraction of whole-plant cereal silages (Johnson et al., 1999). Currently, on-board grain processors are widely accepted as an effective tool to increase kernel breakage, starch digestibility, and milk yield of WPCS for dairy cows (Ferraretto and Shaver, 2012). The improvements in starch digestibility and subsequent milk yield are facilitated by the disruption of the pericarp and starch-protein matrix, a reduction in mean particle size, and an increase in available surface area for microbial attachment. Few published studies have evaluated the effects of varying theoretical length of cut or roll gap settings on WPSS grain breakage and starch digestibility. Johnson (2017) collected 72 samples of WPSS across 6 farms in Kansas, and samples were either unprocessed or processed with a roller mill at roll gap settings of $1.5,1.0$, or $0.5 \mathrm{~mm}$. Samples were analyzed for berry processing score, defined as the percentage of total starch passing through a $1.70-\mathrm{mm}$ sieve, and 7-h starch digestibility. Berry processing score and 7-h starch digestibility increased as the roll gap setting was reduced. Berry processing scores of $26.28,34.64,40.30$, and 55.05 were observed for unprocessed, 1.5-, 1.0-, and $0.5-\mathrm{mm}$ roll gap spacings, respectively. Similarly, 7-h starch digestibility values were $50.54,66.76,68.95$, and 82.07 for the same settings, respectively. The unique agronomic characteristics of sorghum (i.e., drought tolerance, water efficiency, and low cost of production) and the efficiency of modern forage harvesting equipment at breaking corn kernels justify further investigation into the ability of forage harvesters to break sorghum grain. Further research should focus on designing experiments that quantify the relationships among grain breakage, starch digestibility, and lactation performance of dairy cows.

\section{Fermentation of Sorghum Silage}

The silage-making process is divided into 4 phases: (1) aerobic phase, (2) fermentation phase, (3) storage phase, and (4) feed-out phase (Wilkinson and Davies, 2013). During the fermentation phase, lactic acid (the strongest acid produced in the silo with an acid dissociation constant, $\mathrm{p} K_{\mathrm{a}}$ of 3.86 ; Rooke and Hatfield, 2003) becomes the prevalent acid in WPSS. Throughout the storage phase, the acidic environment degrades kafirin proteins, increasing the starch digestibility of the WPSS. A prolonged storage phase is recommended for certain sorghum hybrids that are suspected to contain increased concentrations of tannins or prussic acid. Although the exact mechanism is not known, tannins have been shown to be reduced with increased storage time (Cummins, 1971). Likewise, prussic acid can be reduced during the storage phase of WPSS. Recently, Driehuis et al. (2018) reviewed several published studies and observed lower prussic acid concentrations with increased storage time; however, the majority of prussic acid is removed through gaseous release during its exposure to air, although these losses have not been quantified.

\section{SUPPLEMENTATION OF WPSS AND LACTATION PERFORMANCE}

Most WPSS harvested in the United States is fed to cattle with reduced energy requirements (i.e., dry cows and heifers) because of its higher NDF concentration, lower NDFD, and lower starch concentration and digestibility. However, the effects of supplementing WPSS to lactating dairy cows continue to be evaluated. Aydin et al. (1999) evaluated the effects of supplementing BMR WPSS to lactating dairy cows in 2 experiments. In experiment 1, cows were supplemented either conventional WPSS, BMR WPSS, alfalfa silage, or conventional WPCS at $65 \%$ of diet DM in a $4 \times 4$ Latin square design with 4 wk-periods (Table 3 ). Dry matter intake (\% of BW) was greatest for animals fed a conventional WPCS diet, intermediate for alfalfa silage and BMR WPSS, and lowest for conventional WPSS (4.2, $4.0,3.7$, and $3.5 \%$ of BW, respectively). Likewise, milk yield was greatest for cows fed conventional WPCS, in- 
termediate for those fed alfalfa silage and BMR WPSS, and lowest for cows fed conventional WPSS. Milk yield was increased by $13 \%$ with BMR WPSS compared with cows fed conventional WPSS. No effects on milk fat percentage were observed; however, milk fat yield was greater for conventional WPCS, intermediate for alfalfa silage and BMR WPSS, and lowest for conventional WPSS fed cows $(1.12,0.95,0.89$, and $0.79 \mathrm{~kg} / \mathrm{d}$, respectively). Similarly, milk protein yield was greatest for cows fed conventional WPCS, intermediate for those fed alfalfa silage and BMR WPSS, and lowest for those fed conventional WPSS $(0.99,0.79,0.78$, and $0.68 \mathrm{~kg} / \mathrm{d}$, respectively). Based on these results, BMR WPSS has a greater milk yield potential than conventional WPSS when fed to cows at an inclusion rate of $65 \%$ of diet DM (Aydin et al., 1999).

Experiment 2 (Aydin et al., 1999) elucidated the effects of long-term supplementation of WPSS in a 10-wk continuous lactation trial. Cows were supplemented with either conventional WPSS, BMR WPCS, or conventional WPCS at an inclusion rate of $35.3 \%$ of diet DM (Table 3). No differences were observed in DMI or milk composition among diets. Milk yield was greater with BMR WPSS than with conventional WPSS (36.0 and $33.8 \mathrm{~kg} / \mathrm{d}$ ), whereas cows fed conventional WPCS had milk yields similar to those of other treatments $(34.6 \mathrm{~kg} / \mathrm{d})$. Fat-corrected milk $(4 \%)$ was greatest with BMR WPSS $(33.8 \mathrm{~kg} / \mathrm{d})$ and lowest with conventional WPSS $(31.4 \mathrm{~kg} / \mathrm{d})$; that of conventional WPCS (32.4 $\mathrm{kg} / \mathrm{d}$ ) did not differ from the other treatments. Based on the results of that study, BMR WPSS has the potential to produce similar milk yields to conventional WPCS when included at $35.3 \%$ of diet DM. Similar findings were observed by Oliver et al. (2004), who fed BMR-6 WPSS, BMR-18 WPSS, conventional WPSS, and conventional WPCS to 16 lactating Holstein dairy cows in a replicated Latin square design with 28 -d periods (Table 3 ). An inclusion rate of $40 \%$ of diet DM was used for the 4 forage sources. The BMR- 6 WPSS and conventional WPCS had the greatest milk yield, conventional WPSS had the lowest, and BMR-18 WPSS was similar to that of all treatments $(34.1,33.8,32.2$, and $31.0 \mathrm{~kg} / \mathrm{d}$ milk for BMR-6 WPSS, conventional WPCS, BMR-18 WPSS, and conventional WPSS, respectively). The authors observed a similar trend for milk fat yield (1.34, $1.32,1.22$, and $1.11 \mathrm{~kg} / \mathrm{d}$ for cows fed BMR-6 WPSS, conventional WPCS, BMR-18 WPSS, and conventional WPSS). In a recent meta-analysis, Sánchez-Duarte et al. (2019) observed that BMR WPSS had similar milk yield potential to conventional WPCS in an evaluation of 9 published studies from 1987 to 2015 . These results suggest that with further genetic advancement of sorghum, there is potential for greater supplementation of WPSS to lactating dairy cows.
Journal of Dairy Science Vol. 103 No. 6, 2020

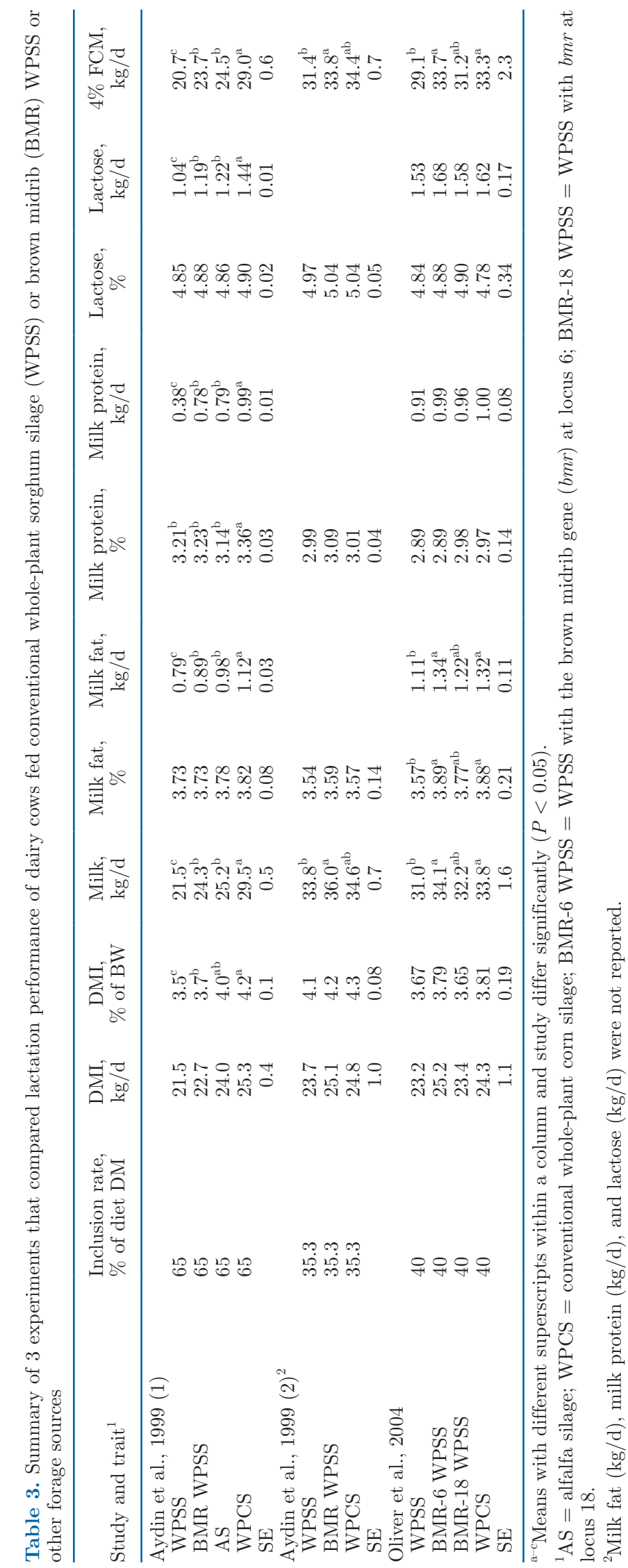


Although great progress has been made to improve the NDFD of WPSS through the BMR trait, careful replacement of WPCS with WPSS is still recommended. Starch concentration and starch digestibility have consistently been lower for WPSS than for WPCS. As discussed earlier, harvesting sorghum at later maturity would allow for greater starch deposition (Lyons et al., 2019); however, digestibility of starch is negatively affected by formation of a more pronounced starchprotein matrix. Early harvesting of sorghum increases starch digestibility but does not allow for adequate starch deposition, resulting in reduced concentrations of starch (Harper et al., 2017). Perhaps the most feasible solution to improve WPSS starch concentration and digestibility is harvesting at a maturity that allows for greater starch deposition and aggressively mechanically processing the grain fraction.

\section{CONCLUDING REMARKS}

Complete substitution of WPSS for WPCS has not been recommended due to increased NDF concentrations, as well as reduced NDFD, starch concentration, and starch digestibility. Recent published literature suggests that genetic improvements via the BMR trait allow BMR WPSS to achieve milk yields similar to that conventional WPCS. The maturity of the crop at harvest can be used to increase starch concentration, and starch digestibility challenges may be alleviated through mechanical processing of the grain fraction of WPSS in a forage harvester. Further research is needed to quantify the effects of forage harvester settings on grain breakage, starch digestibility, and lactation performance. Additionally, the adoption of a berry processing score could aid in quantifying the adequacy of processing. Contemporary sorghum varieties offer vast options of potentially high-yielding and nutrientdense feed sources. Careful hybrid selection, proper silo management, and continued advancement in agronomic and harvesting practices will continue to add value to WPSS as a forage source to dairy cattle.

\section{ACKNOWLEDGMENTS}

The authors have not stated any conflicts of interest.

\section{REFERENCES}

Aydin, G., R. J. Grant, and J. O'Rear. 1999. Brown midrib sorghum in diets for lactating dairy cows. J. Dairy Sci. 82:2127-2135. https: //doi.org/10.3168/jds.S0022-0302(99)75456-1.

Barros, F., J. M. Awika, and L. W. Rooney. 2012. Interaction of tannins and sorghum phenolic compounds with starch and effects on in vitro starch digestibility. J. Agric. Food Chem. 60:11609-11617. https://doi.org/10.1021/jf3034539.
Bernard, J. K., and S. Tao. 2015. Short communication: Production response of lactating dairy cows to brachytic forage sorghum silage compared with corn silage from first or second harvest. J. Dairy Sci. 98:8994-9000. https://doi.org/10.3168/jds.2015-9716.

Conley, S. P., W. G. Stevens, and D. D. Dunn. 2005. Grain sorghum response to row spacing, plant density, and planter skips. Crop Manag. Res. 4:1-8.

Cummins, D. G. 1971. Relationships between tannin content and forage digestibility in sorghum. Agron. J. 63:500-502. https://doi .org/10.2134/agronj1971.00021962006300030046x.

Driehuis, F., J. M. Wilkinson, Y. Jiang, I. Ogunade, and A. T. Adesogan. 2018. Silage review: Animal and human health risks from silage. J. Dairy Sci. 101:4093-4110. https://doi.org/10.3168/jds .2017-13836.

Duodu, K. G., J. R. N. Taylor, P. S. Belton, and B. R. Hamaker. 2003. Factors affecting sorghum protein digestibility. J. Cereal Sci. 38:117-131. https://doi.org/10.1016/S0733-5210(03)00016-X.

Dykes, L., L. W. Rooney, R. D. Waniska, and W. L. Rooney. 2005. Phenolic compounds and antioxidant activity of sorghum grains of varying genotypes. J. Agric. Food Chem. 53:6813-6818. https:// doi.org/10.1021/jf050419e.

Ferraretto, L. F., and R. D. Shaver. 2012. Meta-analysis: Effect of corn silage harvest practices on intake, digestion, and milk production by dairy cows. Prof. Anim. Sci. 28:141-149. https://doi.org/ 10.15232/S1080-7446(15)30334-X.

Gerik, T., B. Bean, and R. Vaderlip. 2003. Sorghum growth and development. Agric. Commun. The Texas A\&M University System, College Station, TX.

Hamaker, B. R., A. A. Mohamed, J. E. Habben, C. P. Hauang, and B. A. Larkins. 1995. Efficient procedure for extracting corn and sorghum kernel proteins reveals higher prolamin contents than the conventional method. Cereal Chem. 72:583-588.

Harper, M. T., J. Oh, F. Giallongo, J. C. Lopes, G. W. Roth, and A. N. Hristov. 2017. Using brown midrib 6 dwarf forage sorghum silage and fall-grown oat silage in lactating dairy cow rations. J. Dairy Sci. 100:5250-5265. https://doi.org/10.3168/jds.2017-12552.

Herrera-Saldana, R. E., J. T. Huber, and M. H. Poore. 1990. Dry matter, crude protein, and starch degradability of five cereal grains. J. Dairy Sci. 73:2386-2393. https://doi.org/10.3168/jds.S0022 $-0302(90) 78922-9$.

Johns, C. O., and J. F. Brewster. 1916. Kafirin, an alcohol-soluble protein from Kafir, Andropogon Sorghum. J. Biol. Chem. 28:59-65.

Johnson, J. 2017. Techniques to increase silage stability and starch availability and the effects of heat stress abatement systems on reducing heat load in dairy cattle. p 90-119. PhD Thesis. Kansas State Univ., Manhattan.

Johnson, L., J. H. Harrison, C. Hunt, K. Shinners, C. G. Doggett and D. Sapienza. 1999. Nutritive value of corn silage as affected by maturity and mechanical processing: A contemporary review. J. Dairy Sci. 82:2813-2825. https://doi.org/10.3168/jds.S0022 -0302(99) 75540-2.

Lyons, S. E., Q. M. Ketterings, G. S. Godwin, D. J. Cherney, J. H. Cherney, M. E. Van Amburgh, J. J. Meisinger, and T. F. Kilcer. 2019. Optimal harvest timing for brown midrib forage sorghum yield, nutritive value, and ration performance. J. Dairy Sci. 102:7134-7149. https://doi.org/10.3168/jds.2019-16516.

M'Khaitir, Y. O., and R. L. Vanderlip. 1992. Grain sorghum and pearl millet response to date and rate of planting. Agron. J. 84:579-582. https://doi.org/10.2134/agronj1992.00021962008400040007x.

Marsalis, M. A., S. V. Angadi, and F. E. Contreras-Govea. 2010. Dry matter yield and nutritive value of corn, forage sorghum, and BMR forage sorghum at different plant populations and nitrogen rates. Field Crops Res. 116:52-57. https://doi.org/10.1016/j.fcr 2009.11.009.

McAllister, T. A., L. M. Rode, D. J. Major, K. J. Cheng, and J. G. Buchanan-Smith. 1990. Effect of ruminal microbial colonization on cereal grain digestion. J. Anim. Sci. 70:571-579. https://doi.org/ 10.4141/cjas90-069.

McCollum, T., K. McCuistion, and B. Bean. 2005. Brown midrib and photoperiod sensitive forage sorghums. Pages $36-46$ in Plains Nu- 
trition Counc. Spring Conf., San Antonio, TX. Plains Nutrition Council, Amarillo, TX.

Oliver, A. L., R. J. Grant, J. F. Pedersen, and J. O'Rear. 2004. Comparison of brown midrib-6 and -18 forage sorghum with conventional sorghum and corn silage in diets of lactating dairy cows. J. Dairy Sci. 87:637-644. https://doi.org/10.3168/jds.S0022 -0302(04)73206-3.

Owens, F. N., R. Zinn, and Y. K. Kim. 1986. Limits to starch digestion in the ruminant small intestine. J. Anim. Sci. 63:1634-1648. https: //doi.org/10.2527/jas1986.6351634x.

Porter, K. S., J. D. Axtell, V. L. Lechtenberg, and V. F. Colenbrander. 1978. Phenotype, fiber composition, and in vitro dry matter disappearance of chemically induced brown midrib (BMR) mutants of sorghum. Crop Sci. 18:205-208. https://doi.org/10.2135/ cropsci1978.0011183X001800020002x.

Rooke, J. A., and R. D. Hatfield. 2003. Biochemistry of ensiling. Pages $95-139$ in Silage Science and Technology. American Society of Agronomy, Madison, WI.

Rotz, C. A., S. Ford, and D. Buckmaster. 2003. Silages in farming systems. Pages 505-546 in Silage Science and Technology. American Society of Agronomy, Madison, WI.

Sánchez-Duarte, J. I., K. F. Kalscheur, A. D. Garcia, and F. E. Contreras-Govea. 2019. Short communication: Meta-analysis of dairy cows fed conventional sorghum or corn silages compared with brown midrib sorghum silage. J. Dairy Sci. 102:419-425. https:// doi.org/10.3168/jds.2018-14552.

Sang, Y., S. Bean, P. A. Seib, J. Pedersen, and Y.-C. Shi. 2008. Structure and functional properties of sorghum starches differing in amylose content. J. Agric. Food Chem. 56:6680-6685. https://doi .org/10.1021/jf800577x.

Sattler, S. E., D. L. Funnell-Harris, and J. F. Pedersen. 2010. Brown midrib mutations and their importance to the utilization of maize, sorghum, and pearl millet lignocellulosic tissues. Plant Sci 178:229-238. https://doi.org/10.1016/j.plantsci.2010.01.001.

Shull, J. M., A. Chandrashekar, A. W. Kirleis, and G. Ejeta. 1990. Development of sorghum (Sorghum bicolor (L.) Moench) endosperm in varieties of varying hardness. Food Struct. 9:253-267.
Sonon, R. N. Jr., and K. K. Bolsen. 1996. Effects of cultivar and stage of maturity on agronomic characteristics, chemical composition, and nutritive value of forage sorghum silages. Adv. Agric. Res. $5: 1-17$.

Staggenborg, S., K. C. Dhuyvetter, and W. B. Gordon. 2008. Grain sorghum and corn comparisons: yield, economic and environmental responses. Agron. J. 100:1600-1604. https://doi.org/10.2134/ agronj2008.0129.

USDA-NASS (National Agricultural Statistics Service). 2018. Sorghum, Silage - Acres Harvested. Accessed May 4, 2018. https: //www.nass.usda.gov/Statistics_by_Subject/index.php?sector= CROPS

Van Amburgh, M. E., E. A. Collao-Saenz, R. J. Higgs, D. A. Ross, E. B. Recktenwald, E. Raffrenato, L. E. Chase, T. R. Overton, J. K. Mills, and A. Foskolos. 2015. The Cornell Net Carbohydrate and Protein System: Updates to the model and evaluation of version 6.5. J. Dairy Sci. 98:6361-6380. https://doi.org/10.3168/jds.2015 $-9378$.

Waldo, D. R. 1977. Potential of chemical preservation and improvement of forages. J. Dairy Sci. 60:306-326. https://doi.org/10.3168/ jds.S0022-0302(77)83870-8.

Wilkinson, J. M., and D. R. Davies. 2013. The aerobic stability of silage: Key findings and recent developments. Grass Forage Sci. 68:1-19. https://doi.org/10.1111/j.1365-2494.2012.00891.x.

\section{ORCIDS}

C. L. McCary (이 https://orcid.org/0000-0002-1960-2453

D. Vyas (ㄴ) https://orcid.org/0000-0002-7657-0267

A. P. Faciola @ https://orcid.org/0000-0003-0935-6233

L. F. Ferraretto ๑ https://orcid.org/0000-0003-4711-8332 